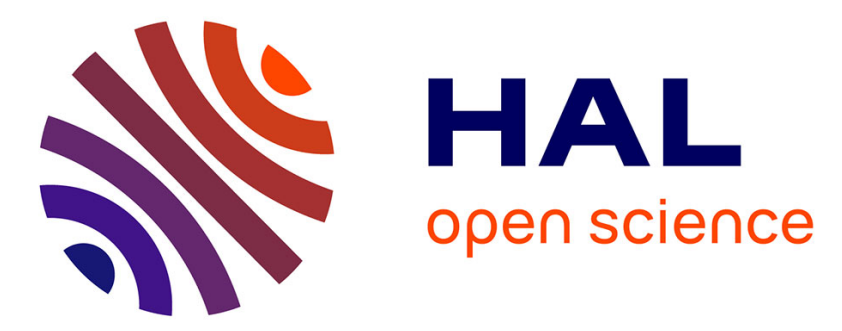

\title{
Production performance, carcass composition, and adipose tissue traits of heavy pigs. Influence of breed and production system
}

Bénédicte Lebret, Jean-Yves Dourmad, Jacques Mourot, Pierre-Yves Pollet, Florence Gondret

\section{To cite this version:}

Bénédicte Lebret, Jean-Yves Dourmad, Jacques Mourot, Pierre-Yves Pollet, Florence Gondret. Production performance, carcass composition, and adipose tissue traits of heavy pigs. Influence of breed and production system. Journal of Animal Science, 2014, 92 (8), pp.3543-3556. 10.2527/jas20147398 . hal-01210604

\section{HAL Id: hal-01210604 \\ https://hal.science/hal-01210604}

Submitted on 28 May 2020

HAL is a multi-disciplinary open access archive for the deposit and dissemination of scientific research documents, whether they are published or not. The documents may come from teaching and research institutions in France or abroad, or from public or private research centers.
L'archive ouverte pluridisciplinaire HAL, est destinée au dépôt et à la diffusion de documents scientifiques de niveau recherche, publiés ou non, émanant des établissements d'enseignement et de recherche français ou étrangers, des laboratoires publics ou privés. 


\section{JOURNAL OF ANIMAL SCIENCE \\ The Premier Journal and Leading Source of New Knowledge and Perspective in Animal Science}

Production performance, carcass composition, and adipose tissue traits of heavy pigs: Influence of breed and production system

B. Lebret, J. Y. Dourmad, J. Mourot, P. Y. Pollet and F. Gondret

J ANIM SCI 2014, 92:3543-3556.

doi: $10.2527 /$ jas.2013-7398

The online version of this article, along with updated information and services, is located on the World Wide Web at:

http://www.journalofanimalscience.org/content/92/8/3543 


\title{
Production performance, carcass composition, and adipose tissue traits of heavy pigs: Influence of breed and production system ${ }^{1}$
}

\author{
B. Lebret, $* \uparrow^{2}$ J. Y. Dourmad, $* \dagger$ J. Mourot, $* \dagger$ P. Y. Pollet, + and F. Gondret* $\uparrow$ \\ *INRA, UMR1348 PEGASE, F-35590 Saint-Gilles, France; †Agrocampus Ouest, \\ UMR1348 PEGASE, F-35000 Rennes, France; and \$Filière Porc Basque, F-64430 Les Aldudes, France
}

\begin{abstract}
Both breed and production systems are responsible for production efficiency and quality traits of pork. Effects of breed and production system within breed on growth, body fatness, and adipose tissues traits were assessed in the pure Basque (B, nonselected, local French) and conventional Large White (LW) breeds, reared either in a conventional ( $\mathrm{C}$, slatted floor), alternative (A, indoor straw bedding and outdoor area), or extensive (E, free range) system. A total of 100 castrated males were produced in 2 replicates, each involving 50 pigs distributed in 5 treatments based on breed and production system (i.e., BC, BA, BE, LWC, and LWA [10 pigs/group and per replicate]). From $35 \mathrm{~kg}$ BW to slaughter at around $145 \mathrm{~kg}$ $\mathrm{BW}$, the BC, BA, LWC, and LWA pigs received the same growing and finishing diets, whereas the BE pigs had free access to the natural resources of the $\mathrm{E}$ pen and received a standard growing-finishing diet at restricted allowance according to the farming practices of the $\mathrm{B}$ pork chain. The B pigs had lower $(P<0.001)$ ADG and G:F than the LW pigs and were much older $(P<0.001)$ at slaughter. The LWA pigs had similar ADG but lower $(P=0.03) \mathrm{G}$ :F than the LWC. Within the B breed, the BA had higher $(P=0.04)$
\end{abstract}

and the $\mathrm{BE}$ lower $(P<0.001) \mathrm{ADG}$ compared with $\mathrm{BC}$ pigs. The $\mathrm{B}$ pigs had a higher $(P<0.001)$ carcass dressing an exhibited around 2-fold higher $(P<0.001)$ back fat proportion, perirenal fat weight and LM lipid content than the LW pigs. Compared with $\mathrm{C}$, the A system decreased $(P=0.04)$ carcass dressing within LW but did not influence carcass traits within B pigs. The E system decreased $(P \leq 0.05)$ carcass dressing, back fat proportion, and LM lipid content in $\mathrm{BE}$ compared with $\mathrm{BC}$ pigs. The $\mathrm{B}$ pigs exhibited larger $(P<0.001)$ adipocytes in both subcutaneous adipose tissue (SCAT) and LM than the LW pigs. Malic enzyme activity was higher in SCAT of B than LW pigs despite their greater fatness, and was higher $(P \leq 0.01)$ in BA but lower $(P<0.001)$ in BE than in BC pigs. The $\mathrm{B}$ pigs had higher $(P<0.001)$ MUFA but lower $(P \leq 0.006)$ SFA and PUFA fatty acid percentages in SCAT than the LW pigs. Compared with C, the A system had scarce influence on FA composition within each breed, whereas the E system led to lower $(P=0.015)$ SFA and greater $(P<$ $0.001)$ PUFA in SCAT of the B pigs. Altogether, the E production system can counteract the genetic potential of B pigs for growth rate but also body fatness.

Key words: carcass quality, extensive production system, growth rate, local breed, pig, subcutaneous adipose tissue

(C) 2014 American Society of Animal Science. All rights reserved.

J. Anim. Sci. 2014.92:3543-3556 doi:10.2527/jas2013-7398

\footnotetext{
${ }^{1}$ The authors thank the staff of INRA experimental farm, slaughterhouse, and laboratories (especially N. Bonhomme, S. Tacher, and M. Fillaut) for excellent assistance and the breeders and slaughterhouse staff of the Basque Pork chain involved in this study. The authors gratefully acknowledge financial participation from the European Community under the Sixth Framework Programme for Research, Technological Development and Demonstration Activities, for the Integrated Project Q-PORKCHAINS FOODCT-2007-036245. The views expressed in this publication are the sole responsibility of the authors and do not necessarily reflect
}

\footnotetext{
the views of the European Commission. Neither the European Commission nor any person acting on behalf of the Commission is responsible for the use which might be made of the information. The information in this document is provided as is and no guarantee or warranty is given that the information is fit for any particular purpose. The user thereof uses the information at its sole risk and liability.

${ }^{2}$ Corresponding author: Benedicte.Lebret@rennes.inra.fr

Received November 18, 2013.

Accepted May 18, 2014.
} 


\section{INTRODUCTION}

Growth performance and body composition impact the efficiency of pig production and the quality of pork. The growing market demand for lean meat has directed pig breeding programs to increased daily weight gain and decreased carcass fatness, leading to improved growth rate, feed efficiency, and carcass lean meat content over the last 40 yr (Stewart et al., 1991; Tribout et al., 2010). However, detrimental effects of selection on some meat quality traits that play an important role in consumer acceptance of pork like visual marbling and intramuscular fat content, color, and mechanical firmness, have also been observed (Schwab et al., 2006). In contrast, local pig breeds that did not undergo selection programs still exhibit slow growth rate and high body fatness and lead to typical and high eating quality pork and pork products (Lopez-Bote, 1998; Bonneau and Lebret, 2010; Pugliese and Sirtori, 2012). Major breed differences for pig production and quality traits are well established (Sellier, 1998). They may interact with production systems such as extensive rearing conditions and heavy slaughter BW, which are notably encountered in traditional systems of Mediterranean regions, to determine production efficiency and eating quality of pork (Lebret, 2008).

To decipher breed and environment influences on growth, body composition, and pork quality, a study was undertaken to compare the local Basque breed exhibiting low growth rate, high carcass fatness, and improved quality pork and the conventional Large White breed, 2 genetically distant European pig breeds (Laval et al., 2000) that were reared in contrasted production systems known to influence performance and quality traits (Labroue et al., 2000; Lebret et al., 2006). The present work aims at understanding the differences in growth, carcass fatness, and chemical and physiological features of adipose tissues according to breed and production system within breed in heavy pigs.

\section{MATERIALS AND METHODS}

The experiments were conducted following French guidelines for animal care and use edited by the French Ministries of High Education and Research, and of Agriculture and Fisheries (http://ethique.ipbs.fr/sdv/ charteexpeanimale.pdf). All animals were reared and slaughtered in compliance with national regulations and according to procedures approved by the French Veterinary Services. Our research unit was holder of a pig experimentation agreement (No. C-35-275-32) and all the technical and scientific staff involved in the experiment had an individual agreement for experimentation on living animals, delivered by the Veterinary Services of the French Ministry of Agriculture.

\section{Animals and Experimental Design}

The experiment involved 2 pure breeds of pigs, the local Basque $(\mathbf{B})$ breed and a selected Large White $(\mathbf{L W})$ line. The B breed (around 500 sows in 2014) is used in a local pork chain located in the southwest of France, producing high eating quality pork products and involved in a Protected Designation of Origin (European label) approach (European registration in progress in 2014). The experiment comprised 2 replicates (R1 and $\mathbf{R 2}$ ) undertaken in 2 successive years, each including a total of 50 castrated males (i.e., $n=30 \mathrm{~B}$ and $n=20 \mathrm{LW}$ pigs). The $\mathrm{B}$ pigs were issued from 2 breeding farms of the $\mathrm{B}$ production chain (Anhaux, 64220 and Lantabat, 64640, France), and the LW pigs were issued from the INRA experimental farm herd (Le Magneraud, 17700 Surgères, and Saint-Gilles, 35590, France). All pigs were free of the HAL $\mathrm{n}$ and $\mathrm{RN}^{-}$alleles.

In each replicate, $20 \mathrm{~B}$ littermates (issued from 10 litters and 6 boars in both R1 and R2) and $20 \mathrm{LW}$ littermates (issued from 10 litters and 9 boars in R1 and 7 litters and 7 boars in R2) were reared in 2 different housing systems at the INRA experimental farm (Saint-Gilles, France) with 10 pigs of each breed in each system. At the average BW of $35 \mathrm{~kg}$, littermates were chosen to balance for BW and average growth rate from birth up to $35 \mathrm{~kg}$ between groups. They were placed in either a conventional $(\mathbf{C})$ housing system on slatted floor (1 pen per breed, $1.0 \mathrm{~m}^{2} /$ pig) or an alternative (A) housing system with indoor bedding and free permanent access to an outdoor area on concrete floor ( 1 pen per breed, $2.4 \mathrm{~m}^{2} / \mathrm{pig}$ ), so that four treatments were considered: the $\mathbf{B C}$ and $\mathbf{L W C}$ groups for B and LW pigs, respectively, housed in C system, and the BA and LWA groups for B and LW pigs, respectively, housed in the A system. The mean daily temperature was lower with greater fluctuations in the A compared with $\mathrm{C}$ system (A system: $17.8 \pm 4.0^{\circ} \mathrm{C}$ and $13.0 \pm 6.2^{\circ} \mathrm{C}$ in the indoor and outdoor areas, respectively, in $\mathrm{R} 1$, and $17.0 \pm$ $4.1^{\circ} \mathrm{C}$ and $10.9 \pm 6.8^{\circ} \mathrm{C}$, respectively, in $\mathrm{R} 2$; C system: $21.9 \pm 1.3^{\circ} \mathrm{C}$ in $\mathrm{R} 1$ and $22.2 \pm 1.0^{\circ} \mathrm{C}$ in $\mathrm{R} 2$ ).

In each replicate, $10 \mathrm{~B}$ castrated males, half-littermates of the $\mathrm{BC}$ and BA pigs, were also placed from 35 $\mathrm{kg} \mathrm{BW}$ onward in an extensive (E) free-range production system in a farm of the B pork chain consortium (Banca, 64430, France), to constitute the fifth treatment: group BE. The BE piglets were born from the previous birth batch of the BA and BC piglets and were issued from 9 litters and 6 boars in R1 (including 4 common boars with $\mathrm{BA}$ and $\mathrm{BC}$ ) and from 9 litters and 7 boars in R2 (including 5 common boars with $\mathrm{BA}$ and $\mathrm{BC}$ ). The BE pigs were reared in a pen of 2.5 ha with a shed (650 m height) together with 30 nonexperimental additional pure B piglets of similar BW and born in the same farrowing farm as the experimental BE pigs. 
Expecting differences in ADG between breeds and production systems (Labroue et al., 2000; Alfonso et al., 2005, Lebret et al., 2006), the BE pigs were put on experiment 5 mo and the $\mathrm{BC}$ and BA pigs 3 mo before the LWC and LWA pigs, to slaughter all pigs at the same time and final BW (around $145 \mathrm{~kg}$ ).

Pigs in both $\mathrm{C}$ and $\mathrm{A}$ housing systems received the same growing diet from $35 \mathrm{~kg}$ up to $75 \mathrm{~kg} \mathrm{BW}$ (2.29 Mcal of NE $/ \mathrm{kg}, 18.0 \% \mathrm{CP}, 3.40 \%$ crude fat, $0.83 \%$ digestible lysine) and a finishing diet thereafter (2.14 Mcal of NE/ $\mathrm{kg}, 14.7 \% \mathrm{CP}, 1.60 \%$ crude fat, $0.75 \%$ digestible lysine). They had free access to feed until the average feed intake of $2.5 \mathrm{~kg} / \mathrm{d}$ and per pig was reached, which corresponded approximately to $75 \mathrm{~kg} \mathrm{BW}$ in each treatment. Then, the daily feed allowance was progressively increased up to $3.0 \mathrm{~kg} / \mathrm{d}$ and per pig up to $110 \mathrm{~kg} \mathrm{BW}$ and maintained at $3.0 \mathrm{~kg} / \mathrm{d}$ and per pig until $145 \mathrm{~kg} \mathrm{BW}$. The BE pigs were reared in the E pen from March up to January (R1) or from April to February (R2). They had free access to the natural resources comprising mainly grass, acorns, and chestnuts and received a standard growing-finishing commercial diet $(2.15 \mathrm{Mcal}$ of NE/kg, $15.5 \% \mathrm{CP}, 1.95 \%$ crude fat, $0.70 \%$ digestible lysine). This diet was distributed according to the farming practices of the B pork chain, with $1.4 \mathrm{~kg} / \mathrm{d}$ up to $2.2 \mathrm{~kg} / \mathrm{d}$ and per pig from $35 \mathrm{~kg}$ up to $75 \mathrm{~kg} \mathrm{BW} ; 2.2 \mathrm{~kg} / \mathrm{d}$ up to $2.6 \mathrm{~kg} / \mathrm{d}$ and per pig from $75 \mathrm{~kg}$ up to $110 \mathrm{~kg} \mathrm{BW} ; 2.6 \mathrm{~kg} / \mathrm{d}$ to $2.3 \mathrm{~kg} / \mathrm{d}$ and per pig from $110 \mathrm{~kg}$ up to $130 \mathrm{~kg} \mathrm{BW}$; and $2.0 \mathrm{~kg} / \mathrm{d}$ and per pig from $130 \mathrm{~kg}$ until slaughter at around $145 \mathrm{~kg} \mathrm{BW}$. In each treatment, pigs had permanent free access to water. The BC, BA, LWC, and LWA pigs were weighed weekly, and the feed consumption per pen (distribution minus refusals) was recorded weekly. The BE pigs were weighed 3 times during the experimental period. The ADFI and G:F were calculated per pen for each group except for the BE pigs, for which feed consumption involved both the commercial diet (for which quantities distributed but not the actual intake were recorded) and the natural resources available on the E pen.

\section{Handling and Slaughtering}

Pigs were slaughtered at the average BW of $145 \mathrm{~kg} \pm$ $9.2 \mathrm{~kg}$. The BC, BA, LWC, and LWA pigs were slaughtered at the experimental slaughterhouse of INRA (UMR PEGASE, Saint-Gilles, France) in 4 sessions each including 8 to 12 pigs. Each slaughtering session involved pigs from the 4 treatments, chosen on the basis of their BW. The BE pigs were slaughtered in 1 session in a commercial slaughterhouse of the B pork chain (SaintJean-Pied de Port, 64220, France). The preslaughter handling of pigs and slaughtering conditions were standardized between the 2 slaughterhouses. Two days prior to slaughter, the animals were given 1.5 times as much as their daily feed allowance; then they were fasted from $2000 \mathrm{~h}$ onward, according to the handling practices of the B pork chain. The next day, pigs were removed from their experimental pen, transported to the slaughterhouse without any mixing with pigs from other groups, and kept in lairage in separate pens for each treatment, where they had free access to water. The next morning, pigs were slaughtered by electrical stunning $(350 \mathrm{~V}-4$ A) and exsanguination, in compliance with the current national regulations applied in slaughterhouses.

\section{Carcass Traits}

Just after slaughter, the hot carcass (trimmed of digestive, reproductive, and respiratory tracts) and perirenal fat were weighed on all pigs. Carcass dressing was calculated as percentage of hot carcass weight to final BW. The thickness of the dorsal subcutaneous adipose tissue (SCAT; without rind) and of its inner and outer constitutive layers were measured using a ruler at the carcass mid line between the fourth and fifth lumbar vertebra level, according to the practice of the B pork chain. The liver, heart, spleen, and kidneys, as well as the digestive tract separated into stomach, small bowel, and colon (full and empty), were weighed in all pigs except the BE ones. After $24 \mathrm{~h}$ of chilling at $4^{\circ} \mathrm{C}$, the cold carcass (except for BE pigs) was weighed, and carcass cooling loss was calculated from the difference between hot and cold carcass weights. In all pigs, the loin, back fat, and ham primary cuts were removed from the right carcass side according to carcass cutting guidelines of the B commercial pork chain and weighed.

\section{Tissue Sampling}

Thirty minutes after slaughter, samples of SCAT including all fat layers were excised from the right carcass side at the last rib level on all pigs from the R1 replicate. The inner and outer layers were then immediately separated, cut in small pieces, frozen in liquid nitrogen, and kept at $-80^{\circ} \mathrm{C}$ until the determination of lipogenic enzyme activities. Another sample was prepared from the outer layer, restrained on flat sticks, frozen in isopentane cooled by liquid nitrogen, and stored at $-80^{\circ} \mathrm{C}$ before cell diameter measurement by histochemistry. The day after slaughter, another sample of SCAT (comprising all fat layers) was taken at the last rib level, put under vacuum, and stored at $-20^{\circ} \mathrm{C}$ before determination of lipid content and fatty acid composition.

Samples of LM (last rib level) were also taken 30 min after slaughter, cut in small pieces following the myofiber longitudinal axis, put on flat sticks, frozen in liquid nitrogen, and stored at $-80^{\circ} \mathrm{C}$ until adipocyte diameter determination by histochemical analysis. The 
day after slaughter, a transverse section of LM (first lumbar vertebra level) was taken, trimmed of external fat, minced and kept under vacuum at $-20^{\circ} \mathrm{C}$ until determination of intramuscular fat (IMF) content.

\section{Tissue Lipid Content}

Lipid contents in SCAT and LM were determined by chloroform:methanol $(2: 1 \mathrm{v} / \mathrm{v})$ extraction following the procedure outlined by Folch et al. (1957). Lipids were extracted from approximately $1 \mathrm{~g}$ of SCAT and $10 \mathrm{~g}$ of LM and expressed as percentage of fresh tissue.

\section{Adipocyte Cellularity in Subcutaneous Adipose and Muscle Tissues}

Adipocyte diameter of SCAT outer layer (R1 replicate) was determined on cross sections of frozen tissue (12- $\mu \mathrm{m}$ thick, $50-\mu \mathrm{m}$ intervals) obtained using a cryostat at $-30^{\circ} \mathrm{C}$ (2800 Frigocut Reicher-Jung, Francheville, France). Considering the high lipid content and adipocyte hypertrophy of some samples, the following modifications were applied to our previously published methodology (Demars et al., 2007). Tissue sections were first fixed for $10 \mathrm{~min}$ in $0.1 \mathrm{M}$ phosphate buffer ( $\mathrm{pH} 7.4$ ) containing $2.5 \%$ (vol/vol) glutaraldehyde ( $25 \%$ aqueous solution, Sigma, St Louis, MO). They were then rinsed 3 times in distilled water and stained for $1 \mathrm{~min}$ in an aqueous solution of Kristal violet indicator $(0.05 \%)$ to reveal cell membranes. Slides were then rinsed in distilled water and mounted under glycerin gelatin.

Images of adipocytes were immediately acquired with a digital camera system (CV-M90; Jai, Glostrup, Denmark). Two slides were prepared per sample and 5 randomly chosen fields exhibiting the best membrane integrity were retained for cellularity analysis in each slide. Cross-section area of each adipocyte cell in each field was measured using a digitizing table and a computer image analysis (Visilog 6.0 Imaging software; Noesis, Courtaboeuf, France). Results corresponding to the mean of determinations in each SCAT sample were expressed as diameter $(\mu \mathrm{m})$, considering adipocytes as spherical cells.

Five serial cross-sections (10 $\mu \mathrm{m}$ thick, $40 \mu \mathrm{m}$ intervals) were also obtained in LM samples using the cryostat equilibrated at $-21^{\circ} \mathrm{C}$. They were then stained with Oil-red-O and counterstained with Kristal violet (Gondret and Lebret, 2002). Several field images of each section were acquired using a digital camera system, and individual cross-section areas of all adipocytes (total of approximately 250 adipocytes per sample) were measured using the digitizing table and the computer image analysis. Results were expressed as average adipocyte diameter $(\mu \mathrm{m})$ for each LM sample.

\section{Fatty acid composition of subcutaneous adipose tissue}

Fatty acid (FA) composition of SCAT was determined ( $\mathrm{R} 1$ replicate) after methylation of fatty acids with boron trifluoride methanol according to procedures developed by Morrison and Smith (1964). Analyses were performed on a gas chromatograph (Nelson Analytical, Manchester, NH) equipped with a fused-silica capillary column $(30-\mathrm{m} \times 0.25-\mathrm{mm}$ internal diameter $)$ with a base-deactivated silica stationary phase (a $0.25-\mu \mathrm{m}$ film thickness) filled with a stationary phase ( $80 \%$ biscyanopropyl and $20 \%$ cyanopropylphenyl) and using margaric acid $(\mathrm{C} 17: 0)$ as the internal standard. The furnace temperature was $180^{\circ} \mathrm{C}$ and injector and detector temperatures were $240^{\circ} \mathrm{C}$. For all samples, retention times and peak areas were determined. The identities of the peaks were checked by comparison with the retention times of standard fatty acid methyl esters. The results were expressed as the percentage of the total FA identified.

\section{Lipogenic Enzyme Activities of Subcutaneous Adipose Tissue}

Lipogenic enzyme activities were determined in inner and outer layers of each SCAT sample (R1 replicate). A weighed quantity of each layer (about 0.5 to $0.7 \mathrm{~g}$ ) was homogenized in $1.5 \mathrm{~mL}$ of ice-cold sucrose $(0.25 \mathrm{M})$ buffer containing $1 \mathrm{~m} M$ dithiothreitol and $1 \mathrm{~m} M$ EDTA. The mixture was then centrifuged at $100,000 \times g$ for $1 \mathrm{~h}$ at $4^{\circ} \mathrm{C}$, and the resulting cytosolic fraction was collected and stored at $-75^{\circ} \mathrm{C}$ until use. Activities of enzymes representing a key step in the formation of palmitic acid (fatty acid synthase [FASN]) or providing a reduced equivalent for fatty acid synthesis (malic enzyme [ME1]) were measured according to the methods described by Bazin and Ferré (2001). Enzyme activities were assayed spectrophotometrically at $340 \mathrm{~nm}$ absorbance following the disappearance (FASN) or the production (ME1) of NADPH. Substrate quantities were optimized ( 50 to $300 \mu \mathrm{L}$ ) to ensure linearity of the reactions. Lipogenic enzyme activities were expressed as nanomoles of NADPH per minute and per gram of tissue.

\section{Statistical Analyses}

The SAS software (version 9.4, 2013, SAS Inst., Cary, NC) was used for statistical analyses.

Data of feed intake and gain-to-feed ratio (experimental unit $=$ pen) were submitted to an ANOVA (GLM procedure) including the treatment (combination of breed and rearing system: 4 levels) and replicate (2 levels) as fixed effects. Contrasts between B and LW breeds and between $\mathrm{A}$ and $\mathrm{C}$ systems within each breed were determined.

For all traits recorded on individuals, homogeneity of variance between treatments was first checked 
(Bartlett test) in an ANOVA including the treatment (5 levels, except for carcass cooling loss and organ weights data: 4 levels) as the main effect. When variance was declared homogeneous (Bartlett test: $P \geq 0.05$ ), data were submitted to an ANOVA (GLM procedure) including the treatment and replicate as fixed effects in the model and final BW as covariate for carcass traits and organ weight data. Contrasts between breeds were determined using A and $\mathrm{C}$ pigs in each breed to balance for rearing system between breeds. Within each breed, contrasts between rearing systems were also determined to evaluate the effects of A vs. C system in the LW breed and A vs. C and $\mathrm{E}$ vs. $\mathrm{C}$ systems in the $\mathrm{B}$ breed. $\mathrm{P}$ values for contrasts between breeds and rearing system within breeds are reported in the tables. When variance was declared nonhomogeneous (Bartlett test: $P<0.05$ ), data were analyzed using a nonparametric method (NPAR1WAY procedure, Kruskal-Wallis test) to determine the effects of breed and rearing system within breed. The influence of SCAT layer on lipogenic enzyme activities was also determined within breed and rearing system within breed using the nonparametric method. P values of Kruskal-Wallis tests are reported in the tables and figures.

Finally, Spearman correlation coefficients were calculated between lipid content and adipocyte diameter within each tissue.

\section{RESULTS}

\section{Growth Performance}

The breed strongly influenced the growth performance of pigs, with the B pigs exhibiting a much lower ADG than the LW pigs during each of the growing and the finishing periods $(P<0.001$; Table 1$)$. Within the LW breed, there was no significant difference in $\mathrm{ADG}$ of pigs between the $\mathrm{A}$ and $\mathrm{C}$ rearing system at each of the growth periods considered. In contrast, within the $\mathrm{B}$ breed, pigs reared in the A system exhibited higher $(P=0.037)$ ADG during the finishing period, thus leading to a higher $(P=0.04)$ ADG over the whole experimental period when compared with $\mathrm{B}$ pigs reared in the $\mathrm{C}$ system. However, the BE pigs exhibited a much lower $(P<0.001)$ ADG than the BC pigs during the first growing and the finishing periods as well as over the whole experimental period. Consequently, the B pigs were much older at slaughter than the LW $(+87 \mathrm{~d}$ on average, $P<0.001)$. Within the $\mathrm{B}$ breed, the $\mathrm{BE}$ pigs were older $(+103 \mathrm{~d}, P<0.001)$ than the BC pigs.

The $\mathrm{B}$ and LW pigs showed rather similar $(P \geq$ $0.09)$ ADFI during the first and second growing periods, whereas the B pigs exhibited a lower $(P=0.002)$ ADFI than the LW pigs during the finishing period. This led to a lower $(P=0.002)$ ADFI over the whole growing-fin- ishing period for the B pigs compared with the LW pigs. The rearing system did not influence $(P \geq 0.61)$ ADFI of pigs within the LW breed, whereas the BA pigs exhibited a greater ADFI during the finishing period and over the whole experimental period $(P \leq 0.009)$ than the $\mathrm{BC}$ pigs. At each phase of the growing and finishing periods, the B pigs showed a lower $(P \leq 0.002) \mathrm{G}$ :F than the LW pigs. Compared with LWC, the LWA pigs exhibited a greater $\mathrm{G}: \mathrm{F}$ during the finishing $(P=0.05)$ and over the whole experimental period $(P=0.03)$, whereas no difference was found for $\mathrm{G}: \mathrm{F}$ between $\mathrm{BA}$ and $\mathrm{BC}$ pigs $(P \geq 0.14)$.

Final BW did not differ between the LW and $\mathrm{B}$ breeds $(P=0.067)$. Within each breed, final $\mathrm{BW}$ was also similar for the LWA and LWC pigs as well as for the $\mathrm{BE}$ and $\mathrm{BC}$ pigs; however, the BA pigs were slightly heavier than the $\mathrm{BC}$ pigs $(+6.4 \mathrm{~kg}, P=0.024)$ at the targeted slaughter BW.

\section{Carcass Traits}

When adjusted to the same final BW, the B pigs exhibited heavier $(P<0.001)$ hot carcass weight and better $(P<0.001)$ carcass yield than the LW pigs (Table 2$)$. Within the LW pigs, the A system led to lower $(P \leq$ $0.005)$ carcass weight and carcass dressing compared with the $\mathrm{C}$ system. Within the $\mathrm{B}$ breed, pigs produced in the $\mathrm{A}$ and $\mathrm{C}$ systems exhibited similar carcass weight and dressing, whereas pigs produced in the E system had lower $(P<0.001)$ hot carcass weight and carcass dressing than $\mathrm{B}$ pigs produced in the $\mathrm{C}$ system.

Major differences were found between breeds for carcass fatness and carcass composition, the B pigs exhibiting a 2-fold higher SCAT thickness than the LW pigs $(P<0.001)$. These differences were associated with variations in the thickness of both the inner and the outer SCAT layers $(P<0.001)$. Similar breed differences $(P<$ $0.001)$ were observed for back fat proportion in the carcass and perirenal fat weight. Conversely, the relative proportions of loin and ham in the carcass were lower for the B pigs than the LW pigs $(P<0.001)$.

Within the LW pigs, the A system led to higher loin percentage $(P=0.002)$ than the $\mathrm{C}$ pigs but did not influence SCAT thickness or the other carcass traits. Within the B pigs, influence of A compared with $\mathrm{C}$ system did not reach significance on SCAT thickness and carcass composition. In contrast, the BE pigs exhibited reduced $(P<0.001)$ SCAT thickness, back fat proportion, and perirenal fat weight and greater $(P<0.001)$ ham percentage than the $\mathrm{BC}$ pigs.

The weights of the internal organs highly depended on breed (Table 3$)$. Indeed, lower $(P<0.001)$ weights of heart, liver, and kidneys, as well as lower empty gastrointestinal tract, stomach, and small bowel were found in the B pigs than in the LW pigs, whereas weights of 
Table 1. Growth performance of pigs according to breed: Large White (LW) or Basque (B) and rearing system: conventional (C), alternative (A), or extensive (E)

\begin{tabular}{|c|c|c|c|c|c|c|c|c|c|}
\hline \multirow[b]{3}{*}{ Item } & \multirow{2}{*}{\multicolumn{5}{|c|}{ Treatment: breed $\times$ rearing system ${ }^{1}$}} & \multicolumn{4}{|c|}{$P$-value ${ }^{2}$} \\
\hline & & & & & & \multirow{2}{*}{$\frac{\text { Breed }}{\text { B vs. LW }}$} & \multicolumn{3}{|c|}{ Rearing system within breed } \\
\hline & LWC & LWA & $\mathrm{BC}$ & $\mathrm{BA}$ & $\mathrm{BE}$ & & LW: A vs. C & B: A vs. C & B: E vs. C \\
\hline No. of pigs & 20 & 19 & 20 & 20 & 20 & & & & \\
\hline No. of pens & 2 & 2 & 2 & 2 & 2 & & & & \\
\hline \multicolumn{10}{|c|}{ First growing period, 35 to $75 \mathrm{~kg}$} \\
\hline Initial live weight ${ }^{3}, \mathrm{~kg}$ & 38.5 & 37.9 & 34.8 & 35.3 & 35.7 & 0.017 & 0.71 & 0.81 & 0.64 \\
\hline Final age ${ }^{4}, \mathrm{~d}$ & 120 & 120 & 170 & 166 & 212 & $<0.001$ & 0.99 & 0.12 & $<0.001$ \\
\hline $\mathrm{ADG}^{4}, \mathrm{~g} / \mathrm{d}$ & 1,033 & 1,035 & 599 & 640 & 358 & $<0.001$ & 0.82 & 0.074 & $<0.001$ \\
\hline $\mathrm{ADFI}^{3,5}, \mathrm{~kg} / \mathrm{d}$ & 2.54 & 2.60 & 2.23 & 2.43 & - & 0.090 & 0.70 & 0.23 & - \\
\hline $\mathrm{G}: \mathrm{F}^{3,5}, \mathrm{~kg} / \mathrm{kg}$ & 0.42 & 0.42 & 0.28 & 0.27 & - & $<0.001$ & 0.22 & 0.34 & - \\
\hline \multicolumn{10}{|c|}{ Second growing period, $75-110 \mathrm{~kg}$} \\
\hline $\mathrm{ADFI}^{3,5}, \mathrm{~kg} / \mathrm{d}$ & 2.78 & 2.80 & 2.51 & 2.64 & - & 0.12 & 0.92 & 0.44 & - \\
\hline $\mathrm{G}: \mathrm{F}^{3,5}, \mathrm{~kg} / \mathrm{kg}$ & 0.25 & 0.25 & 0.20 & 0.20 & - & 0.002 & 0.61 & 0.95 & - \\
\hline \multicolumn{10}{|c|}{ Finishing period, 110 to $145 \mathrm{~kg}$} \\
\hline Final live weight ${ }^{3}, \mathrm{~kg}$ & 148.0 & 144.8 & 139.9 & 146.3 & 141.8 & 0.067 & 0.24 & 0.024 & 0.50 \\
\hline Final age ${ }^{4}, \mathrm{~d}$ & 228 & 230 & 320 & 312 & 423 & $<0.001$ & 0.84 & 0.24 & $<0.001$ \\
\hline $\mathrm{ADG}^{4}, \mathrm{~g} / \mathrm{d}$ & 689 & 659 & 429 & 499 & 236 & $<0.001$ & 0.34 & 0.037 & $<0.001$ \\
\hline $\mathrm{ADFI}^{3,5}, \mathrm{~kg} / \mathrm{d}$ & 3.07 & 3.03 & 2.41 & 2.85 & - & 0.002 & 0.61 & 0.005 & - \\
\hline $\mathrm{G}: \mathrm{F}^{3,5}, \mathrm{~kg} / \mathrm{kg}$ & 0.21 & 0.19 & 0.16 & 0.16 & - & 0.001 & 0.050 & 0.92 & - \\
\hline \multicolumn{10}{|c|}{ Whole growing-finishing period, 35 to $145 \mathrm{~kg}$} \\
\hline $\mathrm{ADG}^{4}, \mathrm{~g} / \mathrm{d}$ & 772 & 755 & 498 & 544 & 335 & $<0.001$ & 0.61 & 0.040 & $<0.001$ \\
\hline $\mathrm{ADFI}^{3,5}, \mathrm{~kg} / \mathrm{d}$ & 2.88 & 2.88 & 2.39 & 2.67 & - & 0.002 & 0.99 & 0.009 & - \\
\hline
\end{tabular}

${ }^{1}$ Means of treatment groups. Experimental unit = pen for data of ADFI and G:F and pig for data of live weight, age and ADG.

${ }^{2} P$-values of contrasts between breeds (determined using A and C pigs of both breeds, i.e. $n=39 \mathrm{LW}$ and $n=40 \mathrm{~B}$ ) or rearing systems within breed obtained from ANOVA, or $P$-values of nonparametric (Kruskal-Wallis) tests for breed and rearing system within breed, in case of heterogeneity of variance of raw data (Bartlett test, $P<0.05$ ).

${ }^{3}$ Data submitted to an ANOVA.

${ }^{4}$ Data submitted to a nonparametric test because of heterogeneity of variance.

${ }^{5}$ Treatment BE was not included in the ANOVA.

spleen and empty colon did not differ between breeds. The digestive content was also lower in the $\mathrm{B}$ than in the LW pigs due to lower $(P<0.001)$ contents within each digestive compartment and especially the colon, compared with LW pigs.

Within each breed, the A and C systems did not influence the weight of liver, heart, and spleen, but weight of kidneys was greater $(P \leq 0.014)$ in $\mathrm{A}$ than in $\mathrm{C}$ systems. The weight of empty gastrointestinal tract did not differ between the $\mathrm{A}$ and $\mathrm{C}$ systems within each breed except a slightly higher $(P=0.047)$ weight of empty small bowel for the LWA than for the LWC pigs and slightly higher $(P=0.041)$ weight of empty stomach for the BA compared with the $\mathrm{BC}$ pigs. Heavier gastrointestinal tract content, due to higher contents of colon $(P=0.002)$ and small bowel to a lesser extent, was also found in the LWA compared with the LWC pigs, whereas no differ- ence were found between BA and BC pigs for weight of gastro-intestinal tract content.

Carcass cooling loss was lower $(P<0.001)$ for the $B$ than the LW pigs. The A rearing system slightly reduced $(P=0.049)$ carcass cooling loss within the LW breed, whereas difference between $\mathrm{A}$ and $\mathrm{C}$ systems for this trait did not reach significance within the B breed.

\section{Lipid Content and Composition in SCAT}

Lipid content in SCAT was greater $(P<0.001)$ in the $B$ breed than in LW breed (Table 4). Within each breed, the $\mathrm{A}$ and $\mathrm{C}$ rearing systems led to similar SCAT lipid contents. However, within the B breed, the E system led to lower $(P<$ 0.001 ) lipid content in SCAT compared to the $\mathrm{C}$ system.

The FA composition of SCAT was also highly influenced by breed. Compared with the LW, the B pigs exhib- 
Table 2. Carcass traits according to breed: Large White (LW) or Basque (B) and rearing system: conventional (C), alternative (A), or extensive (E)

\begin{tabular}{|c|c|c|c|c|c|c|c|c|c|}
\hline \multirow[b]{3}{*}{ Item } & \multirow{2}{*}{\multicolumn{5}{|c|}{ Treatment: breed $\times$ rearing system ${ }^{1}$}} & \multicolumn{4}{|c|}{$P$-value ${ }^{2}$} \\
\hline & & & & & & \multirow{2}{*}{$\begin{array}{c}\text { Breed } \\
\text { B vs. LW }\end{array}$} & \multicolumn{3}{|c|}{ Rearing system within breed } \\
\hline & LWC & LWA & $\mathrm{BC}$ & BA & $\mathrm{BE}$ & & LW: A vs. C & B: A vs. C & B: E vs. C \\
\hline No. of pigs & 20 & 19 & 20 & 20 & 20 & & & & \\
\hline Hot carcass weight, $\mathrm{kg}$ & 115.2 & 114.0 & 117.8 & 117.2 & 115.8 & $<0.001$ & 0.005 & 0.32 & 0.001 \\
\hline Carcass dressing, $\%$ & 80.0 & 78.7 & 81.8 & 81.3 & 80.3 & $<0.001$ & 0.004 & 0.32 & $<0.001$ \\
\hline Subcutaneous adipose tissue depth, $4 / 5 \mathrm{LV}^{3}, \mathrm{~mm}$ & 23.3 & 24.3 & 46.8 & 50.3 & 39.2 & $<0.001$ & 0.46 & 0.059 & $<0.001$ \\
\hline Perirenal fat weight, $\mathrm{kg}$ & 1.86 & 1.86 & 4.78 & 4.78 & 3.99 & $<0.001$ & 0.84 & 0.75 & $<0.001$ \\
\hline $\operatorname{Ham}^{5}, \%$ & 28.4 & 28.4 & 25.8 & 25.8 & 27.6 & $<0.001$ & 0.82 & 0.79 & $<0.001$ \\
\hline Loin, \% & 22.8 & 23.7 & 17.7 & 18.0 & 17.7 & $<0.001$ & 0.002 & 0.34 & 0.84 \\
\hline Backfat, \% & 7.9 & 8.0 & 15.2 & 15.7 & 11.3 & $<0.001$ & 0.68 & 0.45 & $<0.001$ \\
\hline
\end{tabular}

${ }^{1}$ Least-square means of treatment groups. Experimental unit $=$ pig.

${ }^{2} P$-values of contrasts between breeds (determined using A and C pigs of both breeds, i.e. $n=39 \mathrm{LW}$ and $n=40 \mathrm{~B}$ ) or rearing systems within breed obtained from ANOVA (including final BW at slaughter [average of $144.1 \mathrm{~kg}$ ] as covariate). All data in the table were submitted to an ANOVA because of homogeneity of variance (Bartlett test, $P \geq 0.05$ ).

${ }^{3} \mathrm{LV}=$ lumbar vertebrae.

${ }^{4}$ Data recorded for $n=15 \mathrm{BA}, n=17 \mathrm{BC}, n=20 \mathrm{BE}, n=15 \mathrm{LWA}$, and $n=15 \mathrm{LWC}$ pigs.

${ }^{5}$ Proportion of carcass right side.

ited a lower $(P<0.001)$ proportion of SFA due to lower $(P$ $\leq 0.025)$ percentages of all SFA except C14:0. Conversely, the $\mathrm{B}$ pigs had greater $(P<0.001)$ MUFA proportion, which was mainly due to higher proportion of $\mathrm{C} 18: 1 \mathrm{n}-9 \mathrm{FA}(+5 \%$ point on average, $P<0.001)$. The $\mathrm{B}$ pigs also exhibited lower $(P=0.006)$ proportion of PUFA resulting from lower $(P \leq 0.013)$ proportions of $118: 2 \mathrm{n}-6, \mathrm{C} 18: 3 \mathrm{n}-3, \mathrm{C} 18: 4 \mathrm{n}-3$, C20:3 n-6, and C22:5 n-3 in the SCAT of B pigs than LW pigs. The ratios of $\mathrm{C} 18: 2 \mathrm{n}-6$ to $\mathrm{C} 18: 3 \mathrm{n}-3$ and of $n-6$ to $n-3$ PUFA families were similar in the B and LW breeds.

Compared with $\mathrm{C}$, the A rearing system had little influence on the FA composition of SCAT within each breed, with only lower $(P<0.001)$ proportion of $\mathrm{C} 18: 4$ n-3 in LWA pigs compared with LWC pigs and slightly higher $(P \leq 0.038)$ proportions of $\mathrm{C} 20: 3 \mathrm{n}-3$ and $\mathrm{C} 22: 4$ $\mathrm{n}-6$ in the BA compared with $\mathrm{BC}$ pigs. In contrast, the $\mathrm{E}$

Table 3. Weight of organs and carcass cooling loss according to breed: Large White (LW) or Basque (B) and rearing system: conventional (C) or alternative (A)

\begin{tabular}{|c|c|c|c|c|c|c|c|}
\hline \multirow[b]{3}{*}{ Item } & & & & & \multicolumn{3}{|c|}{$P$-value ${ }^{2}$} \\
\hline & \multicolumn{4}{|c|}{ Treatment: breed $\times$ rearing system ${ }^{1}$} & Breed & \multicolumn{2}{|c|}{ Rearing system within breed } \\
\hline & LWC & LWA & $\mathrm{BC}$ & $\mathrm{BA}$ & B vs. LW & LW: A vs. C & B: A vs. C \\
\hline No. of pigs & 19 & 20 & 20 & 20 & & & \\
\hline \multicolumn{8}{|l|}{ Weight of organs, kg } \\
\hline Liver & 2.00 & 2.00 & 1.49 & 1.47 & $<0.001$ & 0.98 & 0.88 \\
\hline Heart & 0.50 & 0.52 & 0.40 & 0.41 & $<0.001$ & 0.21 & 0.74 \\
\hline Spleen & 0.25 & 0.23 & 0.24 & 0.23 & 0.72 & 0.31 & 0.93 \\
\hline Kidneys & 0.37 & 0.41 & 0.32 & 0.35 & $<0.001$ & 0.006 & 0.014 \\
\hline Gastrointestinal tract (empty) & 6.58 & 6.75 & 6.27 & 6.54 & $<0.001$ & 0.28 & 0.087 \\
\hline Stomach & 0.85 & 0.84 & 0.62 & 0.69 & $<0.001$ & 0.83 & 0.041 \\
\hline Small bowel & 1.77 & 1.90 & 1.07 & 1.18 & $<0.001$ & 0.047 & 0.081 \\
\hline Colon & 2.11 & 2.08 & 2.09 & 2.09 & 0.93 & 0.80 & 0.95 \\
\hline Gastrointestinal tract content & 2.46 & 3.09 & 0.93 & 1.06 & $<0.001$ & 0.002 & 0.55 \\
\hline Stomach & 0.69 & 0.58 & 0.09 & 0.19 & $<0.001$ & 0.30 & 0.38 \\
\hline Small bowel & 0.50 & 0.63 & 0.30 & 0.31 & $<0.001$ & 0.022 & 0.92 \\
\hline Colon & 1.30 & 1.78 & 0.53 & 0.65 & $<0.001$ & 0.002 & 0.41 \\
\hline Carcass cooling loss, $\%$ & 2.19 & 2.03 & 1.84 & 1.71 & $<0.001$ & 0.049 & 0.086 \\
\hline
\end{tabular}

${ }^{1}$ Least-square means of treatment groups. Experimental unit $=$ pig.

${ }^{2} P$-values of contrasts between breeds (determined using A and C pigs of both breeds, i.e. $n=39 \mathrm{LW}$ and $n=40 \mathrm{~B}$ ) or rearing systems within breed obtained from ANOVA (including final BW at slaughter [average of $144.1 \mathrm{~kg}$ ] as covariate). All data in the table were submitted to an ANOVA because of homogeneity of variance (Bartlett test, $P \geq 0.05$ ). 
Table 4. Lipid content and fatty acid composition of subcutaneous adipose tissue according to breed: Large White (LW) or Basque (B) and rearing system: conventional (C), alternative (A), or extensive (E)

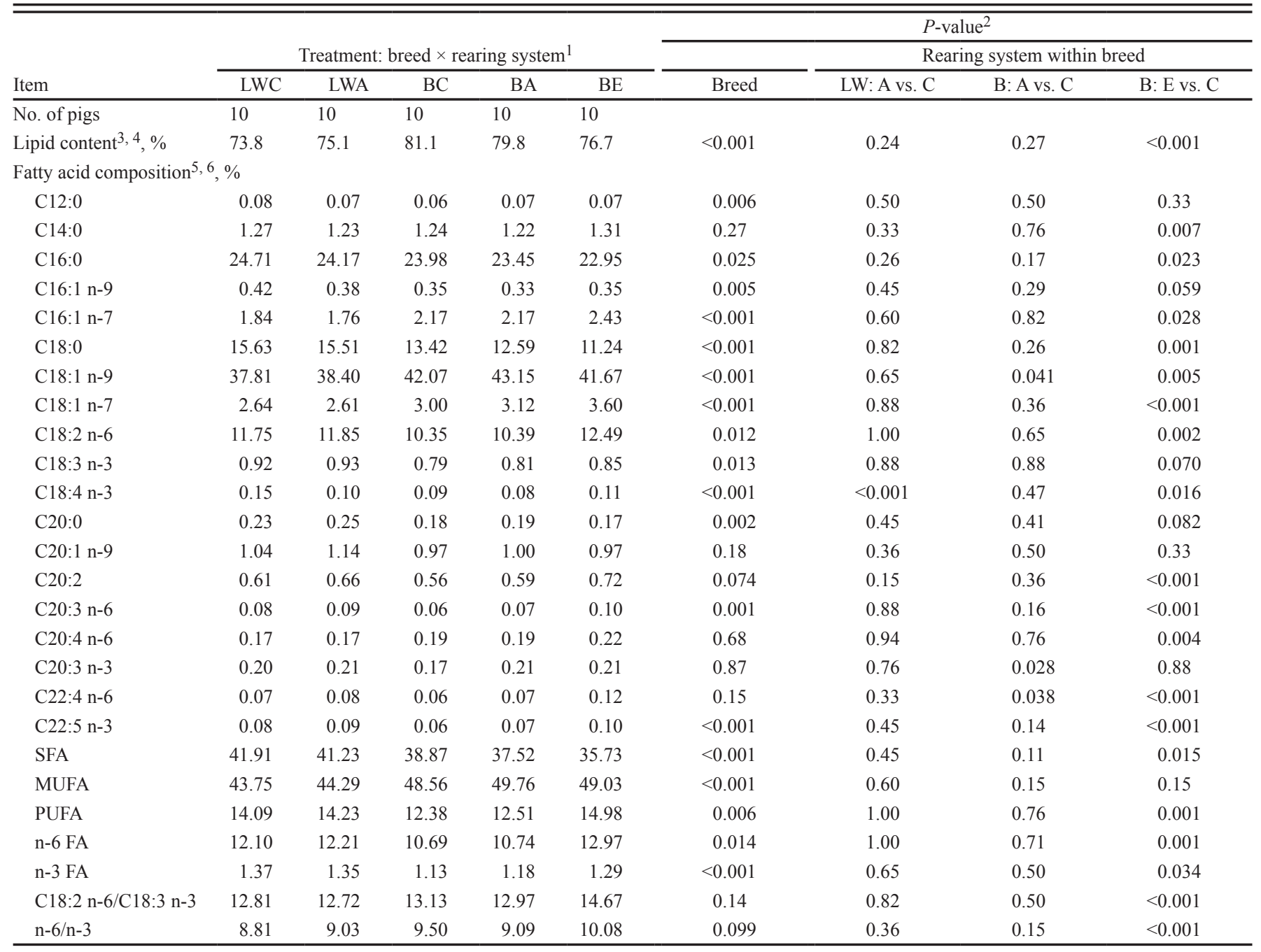

${ }^{1}$ Means of treatment groups. Experimental unit = pig.

${ }^{2} P$-values of contrasts between breeds (determined using A and C pigs of both breeds, i.e. $n=20 \mathrm{LW}$ and $n=20 \mathrm{~B}$ ) or rearing systems within breed obtained from ANOVA, or $P$-values of nonparametric (Kruskal-Wallis) tests for breed and rearing system within breed in case of heterogeneity of variance of raw data (Bartlett test, $P<0.05$ )

${ }^{3}$ Proportion of fresh tissue.

${ }^{4}$ Data submitted to an ANOVA.

${ }^{5}$ Proportion of total fatty acids. Because of the very low proportions (between 0 and 0.04\% according to treatments) of C18:3 n-6, C20:5 n-3, and C22:6 n-3, these data were not presented in the table.

${ }^{6}$ Data submitted to a nonparametric test because of heterogeneity of variance.

system strongly modified the FA composition of SCAT, with lower $(P \leq 0.015)$ SFA proportion, mainly due to lower $(P<0.023) \mathrm{C} 16: 0$ and $\mathrm{C} 18: 0$ in the SCAT of the BE compared with BC pigs. No difference was observed between $\mathrm{BE}$ and $\mathrm{BC}$ pigs for total MUFA proportion because $\mathrm{C} 18: 1 \mathrm{n}-9$ proportion was decreased $(P=0.005)$, but $\mathrm{C} 16: 1 \mathrm{n}-7$ and $\mathrm{C} 18: 1 \mathrm{n}-7$ proportions were increased $(P \leq 0.028)$ in the SCAT of the BE compared with BC pigs. The BE pigs exhibited greater $(P \leq 0.004)$ proportions of all n-6 PUFA, especially the most abundant n-6 PUFA C18:2 n-6 than the BC pigs. System-associated differences were lower for n-3 PUFA, with only slightly greater $(P<0.001)$ proportions of $\mathrm{C} 18: 4 \mathrm{n}-3$ and $\mathrm{C} 22: 5$ $\mathrm{n}-3$ in $\mathrm{BE}$ than in $\mathrm{BC}$ pigs. Therefore, compared with $\mathrm{BC}$, the BE pigs showed higher $(P<0.001)$ PUFA proportion and greater $(P<0.001)$ ratios of $\mathrm{C} 18: 2$ n- 6 to $\mathrm{C} 18: 3 \mathrm{n}-3$ FA and of n- 6 to n-3 PUFA families in the SCAT.

\section{Histological and Metabolic Properties of SCAT}

The B pigs exhibited larger adipocytes $(+35 \%$ on average, $P<0.001)$ in the outer layer of SCAT compared with the LW pigs, whereas adipocyte diameter did not differ according to production system within each breed 
A -

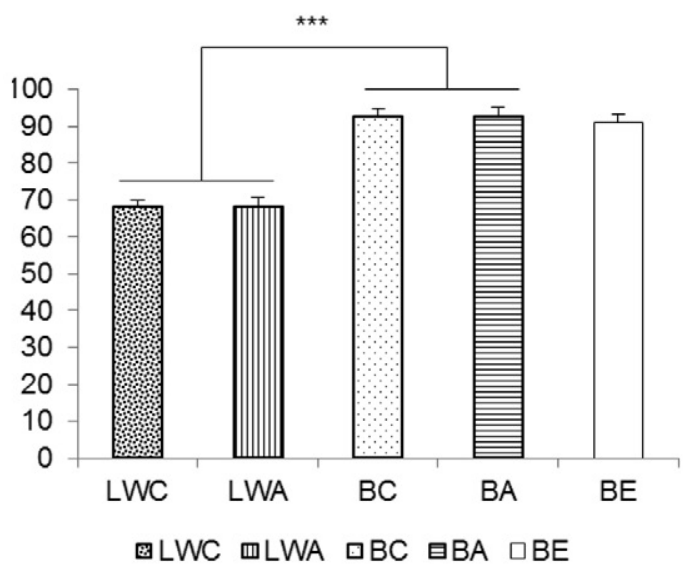

B -

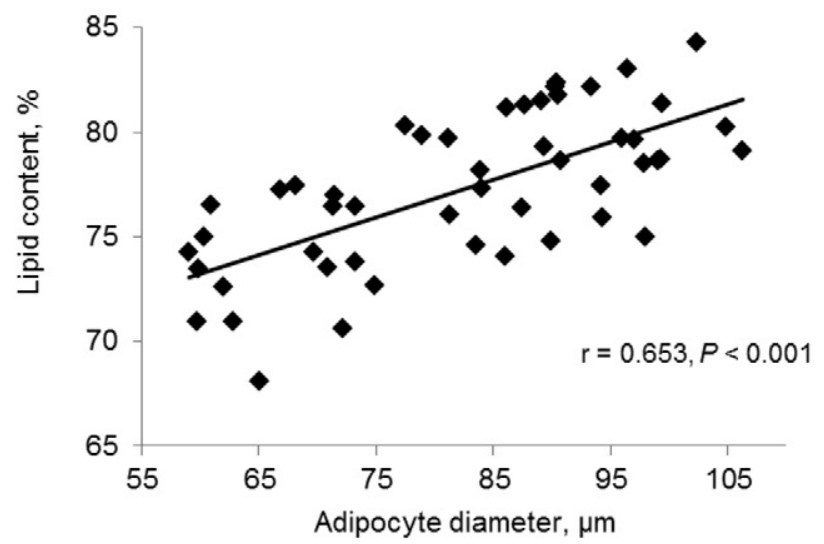

Figure 1. Adipocyte diameter $(\mu \mathrm{m})$ in the outer layer of the subcutaneous adipose tissue. (A) Adipocyte diameter (means \pm standard errors) according to breed (Large White, LW; Basque, B) and production system (conventional, $\mathrm{C}$; alternative, A; extensive, E), $n=10$ per treatment group. Comparisons between breeds were determined using A and $\mathrm{C}$ pigs of both breeds ( $n=20 \mathrm{LW}$ and $n=20 \mathrm{~B}$ ) and using a nonparametric (KruskalWallis) test due to heterogeneity of variance of raw data $(* * *: P<0.001)$. (B) Correlation between adipocyte diameter in the outer layer and total lipid content in the subcutaneous adipose tissue ( $r=$ Spearman correlation coefficient).

(Fig. 1A). Overall, the adipocyte diameter in the outer layer of SCAT was positively correlated $(r=0.65, P<$ 0.01 ) with the total lipid content in SCAT (Fig. 1B).

The activities of FASN, the main lipogenic enzyme, and of ME1, the main supplier of reduced equivalent for de novo lipogenesis, were also affected by breed or by production system (Fig. 2). The FASN activity was similar between breeds regardless of the layer, whereas ME1 activity was lower $(P<0.001)$ in B pigs than in LW pigs in both the inner and outer SCAT layer. This breed difference was accentuated in the inner than the outer layer due to higher $(P=0.002) \mathrm{ME} 1$ activity in the inner than the outer SCAT layer within the LW pigs, whereas ME1 activity did not differ between layers within the B pigs. Within the LW breed, FASN and ME1 activities of SCAT did not differ between A and C systems. Within the B breed, FASN activity did not differ between A and C systems, but was lower $(P \leq 0.05)$ in both SCAT layers of the BE pigs compared with BC pigs. A higher $(P \leq$ $0.01)$ ME1 activity was found in the two SCAT layers of the BA compared with BC pigs, whereas a lower $(P<$ $0.001)$ ME1 activity was observed in the two SCAT layers of the BE compared with BC pigs.

Similar breed or rearing system-associated differences were observed when lipogenic enzymes were expressed per milligram of cytosolic protein (data not shown) even though the range of differences between breeds was slightly lower due to the lower cytosolic protein content of the B compared with the LW pigs.

\section{Intramuscular fat content and adipocyte diameter in LM}

Breed strongly influenced the IMF content of the LM, with higher $(P<0.001)$ IMF content in B breed than in LW breed (Fig. 3A). There were no differences between $\mathrm{A}$ and $\mathrm{C}$ rearing system within each breed, but the $\mathrm{E}$ system led to a lower $(P \leq 0.05)$ IMF content compared with $\mathrm{C}$ within the $\mathrm{B}$ pigs. The $\mathrm{B}$ pigs also displayed larger intramuscular adipocytes $(P<0.001)$ than the LW pigs, without any difference between production systems within each breed (Fig. 3B). Overall, IMF content and adipocyte diameter were highly and positively correlated ( $r=0.74, P<0.001$; Fig. 3C).

\section{DISCUSSION}

\section{Pig Production Traits Were Mainly Affected by Breed and Extensive Production System}

Pigs of the local B breed, which has been preserved by small farmers in France and Spain to provide traditional food markets and did not encounter genetic selection program for improved efficiency of lean meat production (Arrayet et al., 2006), exhibited a much lower growth rate and a lower G:F than the selected LW pigs. The B pigs also exhibited a much greater adiposity at both subcutaneous (higher back fat thickness and percentage), internal (higher perirenal fat weight), and intramuscular fat tissue levels and a lower proportion of loin and ham in the carcass when compared with LW pigs at the same slaughter BW. Similar differences in growth rate, loin percentage or area, back fat thickness, and IMF content have been reported in previous comparative studies between $\mathrm{B}$ and LW breeds raised either in $\mathrm{C}$ or $\mathrm{E}$ conditions and slaughtered at similar age (202 d; Alfonso et al., 2005) or similar BW (100 or $150 \mathrm{~kg} \mathrm{BW}$; Labroue et al., 2000). Other local pig breeds, such as Gascon and Limousin French breeds, generally also exhibit much lower growth rate and higher carcass fatness and IMF content than the LW breed (Labroue 
A -

Fatty acid synthase activity

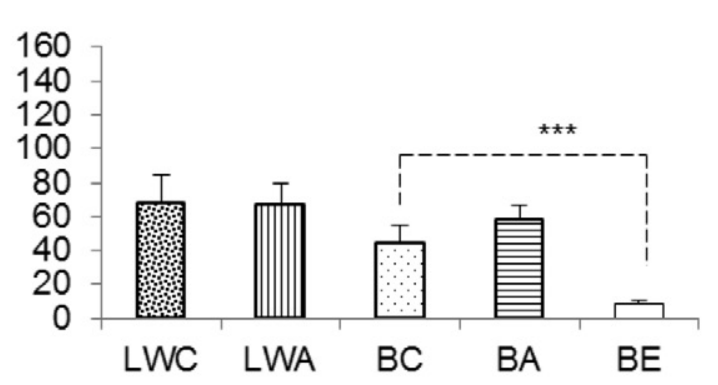

B -

Fatty acid synthase activity

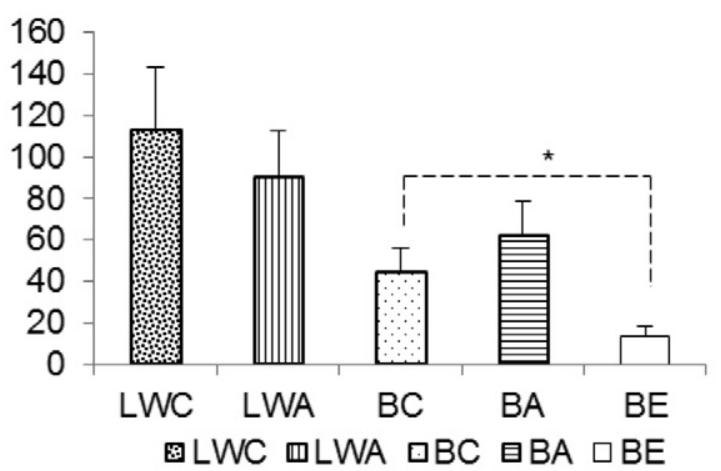

Malic enzyme activity

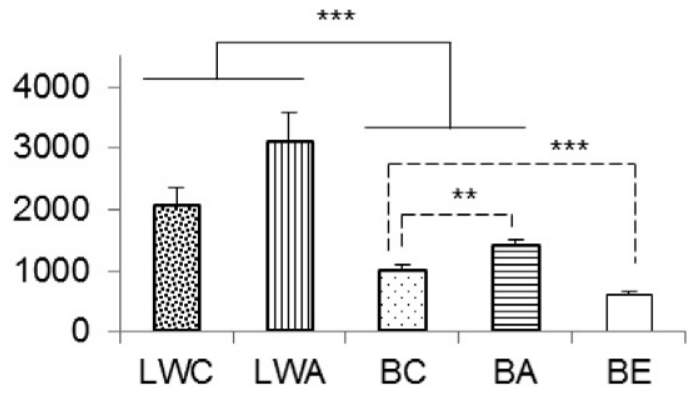

Malic enzyme activity

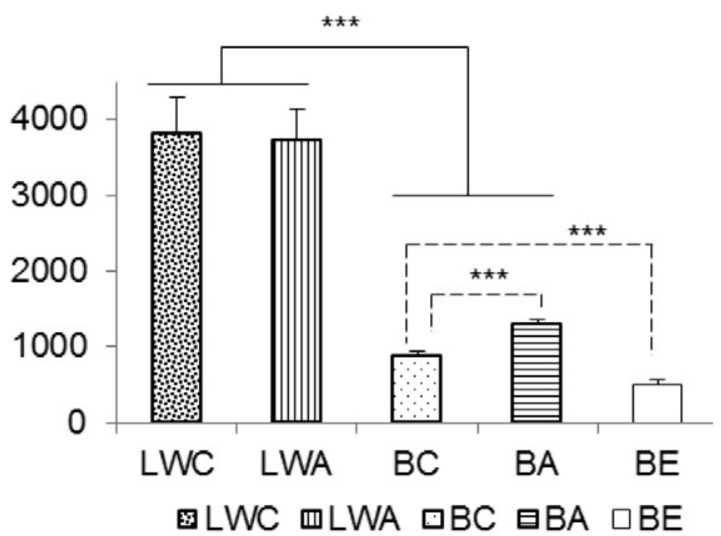

Figure 2. Fatty acid synthase and malic enzyme activities (nmole/min per g of tissue; means \pm standard errors) in the outer (A) and inner (B) layers of the subcutaneous adipose tissue of pigs, according to breed (Large White, LW; Basque, B) and production system (conventional, C; alternative, A; extensive, E); $n=$ 10 per treatment group. Comparisons between breeds (solid line; determined using A and C pigs of both breeds, i.e., $n=20 \mathrm{LW}$ and $n=20 \mathrm{~B}$ ) and comparisons between rearing system within breed (plotted line) were determined using a nonparametric (Kruskal-Wallis) test due to heterogeneity of variance of raw data $(* * *: P<0.001 ; * *: P<0.01 ; *: P<0.05)$.

et al., 2000). Besides genetics, our study adds new evidence on the impact of rearing conditions, especially the E ones, on growth performance and body fat deposition, with lower ADG and back fat thickness at slaughter for the $\mathrm{B}$ pigs produced in the $\mathrm{E}$ system compared with the $\mathrm{C}$ system. Literature studies on the consequences of extensive rearing on pig growth rate and body fatness are rather controversial (Millet et al., 2005), and the discrepancies might be due to differences between studies in climatic conditions, feeding management, and especially feed allowance. Whereas Gentry et al. (2002) did not report any difference in growth rate and back fat thickness of pigs reared outdoor on pasture compared with indoor housing in a mild climate, reduced ADG, carcass fatness, and IMF contents have been observed for pigs reared outdoors in a cold climate (Enfält et al., 1997; Sather et al., 1997; Bee et al., 2004). In the present study, the lower growth rate and carcass fatness of the $\mathrm{BE}$ pigs compared with $\mathrm{BC}$ pigs suggest that the natural resources in the E pen associated with the distribution of a commercial diet at a lower amount in the $\mathrm{E}$ than in the $\mathrm{C}$ system did not fulfill the nutritional requirements of the BE pigs. This may be due to the higher energy requirement for thermoregulation and the greater physical activity of BE pigs resulting from a higher space allowance in extensive conditions (Sather et al., 1997; Bee et al., 2004; Lebret, 2008). The differences were smaller when an A system including an indoor bedding and small outdoor area was compared with the $\mathrm{C}$ indoor system on slatted floor. Higher ADG but similar G:F was observed in $\mathrm{B}$ pigs produced in the $\mathrm{A}$ compared with $\mathrm{C}$ system, whereas the LW pigs produced in the A system exhibited similar ADG but a slightly lower G:F compared with their littermates produced in the $\mathrm{C}$ system. These discrepancies are likely related to differences in feed intake, which was similar in the LWA and LWC pigs, but higher for BA than BC pigs that showed feed refusals. Thereby, present results on $\mathrm{B}$ pigs agree with previous data ob- 
tained on both synthetic line and Duroc crossbred pigs reared in these systems (Lebret et al., 2006, 2011). No differences in subcutaneous fat thickness were observed between $\mathrm{A}$ and $\mathrm{C}$ systems within the $\mathrm{LW}$ as well as within the B pigs, despite the higher feed intake of the BA than $\mathrm{BC}$ pigs. In agreement, Duroc crossbreeds reared in $\mathrm{A}$ and $\mathrm{C}$ systems exhibited a similar carcass fatness (Lebret et al., 2011), whereas fatter carcasses and higher IMF content were found in synthetic line crossbred pigs produced in A compared with $\mathrm{C}$ housing system (Lebret et al., 2006). Contrasted results have also been reported regarding body fatness of pigs reared on bedding or offered larger space allocation, with either greater (Beattie et al., 2000; Gentry et al., 2002) or similar (Guy et al., 2002) carcass fatness and IMF content in alternative and conventional systems, whereas reduced back fat thickness and LM marbling score were found in pigs reared in deep bedding compared with conventional finishing system at similar stocking density (Patton et al., 2008).

The present study highlighted breed differences for carcass dressing with a better carcass yield in the B than in the LW breed, whereas differences in carcass dressing between $\mathrm{B}$ and LW breeds did not reach significance in the study of Labroue et al. (2000). In the present experiment, differences were related to lower weights of many internal organs and of digestive contents in each digestive segment in the $\mathrm{B}$ compared with the LW pigs. Renaudeau and Mourot (2007) have also reported higher carcass yield due to lower weights of digestive tract and internal organs, including heart, liver, and kidneys in the pure Creole pigs, a Caribbean nonselected breed, compared with LW pigs. Altogether, this highlights the advantage of local breeds on this production trait. Influence of A compared to $\mathrm{C}$ system on carcass yield was limited to the LW pigs. The heaviest colon content of the LWA compared with LWC pigs, which has been previously observed in synthetic line crossbred pigs reared in the A compared with the $\mathrm{C}$ housing system (Lebret et al., 2006), was likely due to sawdust consumption by LWA pigs during the fasting period before transport to the slaughterhouse. Because the B pigs exhibited a lower voluntary feed intake than the LW during the finishing period, they may have been less affected by fasting and thereby would exhibit a similar carcass yield in A and $\mathrm{C}$ production systems. In contrast, carcass dressing was much lower for $\mathrm{B}$ pigs produced in the $\mathrm{E}$ than in the conventional system. Unfortunately, the slaughtering conditions did not allow the organs to be collected so we cannot give any definitive explanation for this difference. Finally, breed also influenced carcass cooling loss to the advantage of the B compared with the LW breed and, within each breed, to the A compared with the $\mathrm{C}$ system, confirming previous data on the differences between housing systems (Lebret et al., 2006).
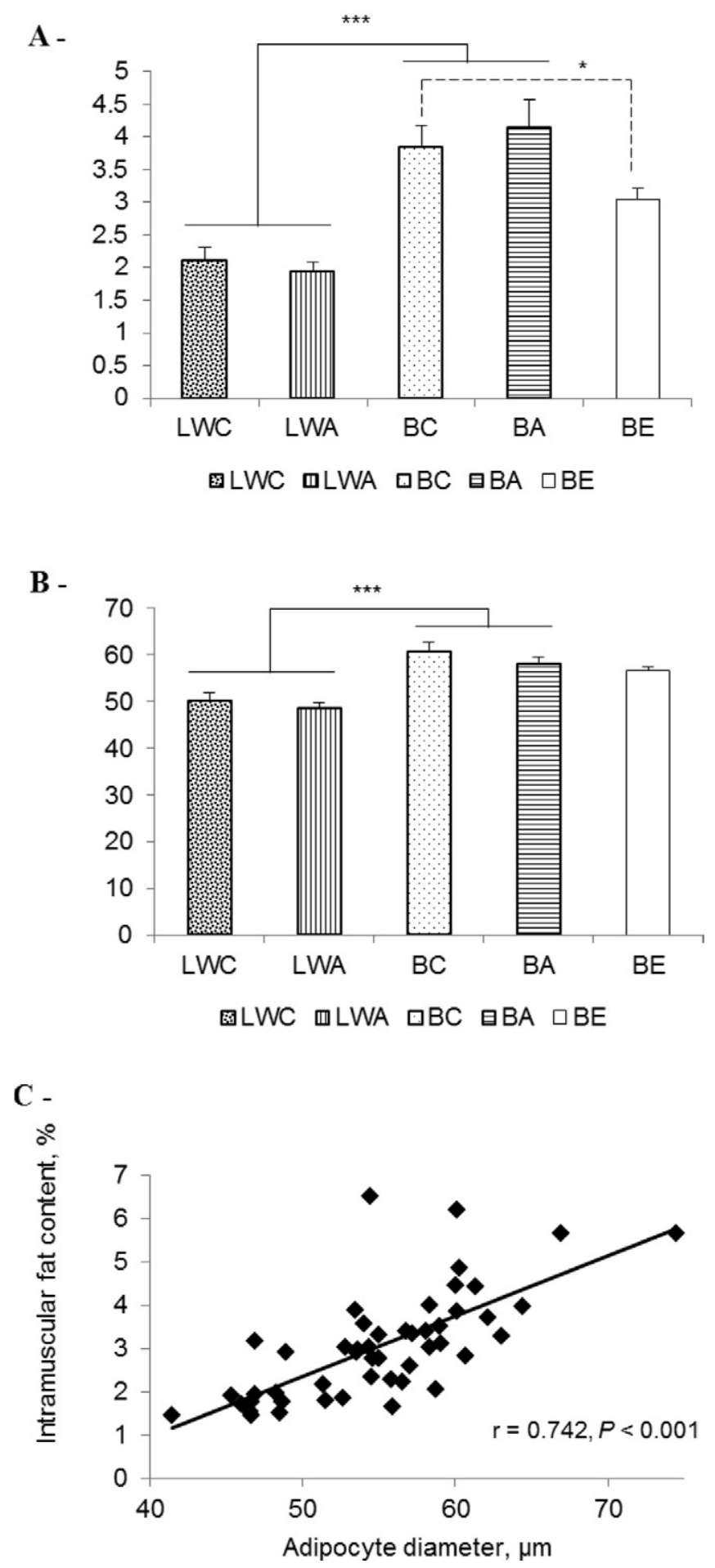

Figure 3. Intramuscular fat content and adipocyte diameter (means \pm standard errors) in the Longissimus muscle (LM). (A) Intramuscular fat content $(\%)$ and $(\mathrm{B})$ adipocyte diameter $(\mu \mathrm{m})$ according to breed (Large White, LW and Basque, B) and production system (conventional, C; alternative, A; extensive, E), $n=10$ per treatment group. Comparisons between breeds (solid line; determined using A and C pigs of both breeds, i.e., $n=20 \mathrm{LW}$ and $n=20$ B) and comparisons between rearing system within breed (plotted line) were determined using a nonparametric (Kruskal-Wallis) test due to heterogeneity of variance of raw data $(* * *: P<0.001 ; *: P<0.05)$. (C) Correlation between adipocyte diameter and intramuscular fat content in the LM $(r=$ Spearman correlation coefficient). 


\section{Composition and Physiology of Subcutaneous Adipose Tissue Depend on Breed and Production System}

The much greater adiposity of the B pigs compared with the LW pigs was associated with the enlargement of the inner and outer layers at the dorsal subcutaneous location. Despite the larger thickness of the inner compared with the outer layer in all pigs, each layer contributed similarly to the treatment-associated differences in back fat thickness. It is difficult to compare our results with previous data regarding the thickness of the subcutaneous fat layers between B and LW breeds (Alfonso et al., 2005), in which the distinction between inner, middle, and outer layers had underlined the major contribution of the middle layer in the overall back fat difference between the two breeds.

The enzyme activities of lipogenesis were greater in the inner compared with the outer layer of SCAT as expected (Anderson et al., 1972; Hood and Allen, 1973; Lefaucheur et al., 1991). Fatty acid synthase activity did not differ between breeds, but malic enzyme activity was much lower for the B pigs when compared with the LW pigs. This variation was somewhat unexpected because elevated lipogenic activities have been previously reported in SCAT of fat lines compared to lean pig lines at constant BW of $109 \mathrm{~kg}$ (Hood and Allen, 1973) or at a constant age of 6 mo (Steele and Frobish, 1976; Scott et al., 1981a). The older age of pigs in the present study and the breed-related differences in age at the same heavy BW at slaughter (7.5 mo for LWA and LWC pigs and 10.5 mo for BA and BC pigs, respectively) were likely responsible for this result. Indeed, the lipogenic capacity of pig adipose tissues first increases after weaning, peaks, and then decreases as a consequence of a less-functional adipocyte cytoplasm, although the time points at each steps depend both on the pig genotype and the lipogenic enzyme considered (Anderson and Kauffman, 1973; Scott et al., 1981a; Gardan et al., 2006). Furthermore, the age-related decrease in lipogenic activity of SCAT, especially those of the NADPH-supplier malic enzyme, has been found more important in the fat Meishan than in the lean LW breed (Mourot et al., 1996). Indeed, greater malic enzyme activity was previously measured in $\mathrm{B}$ than in LW pigs compared at $35 \mathrm{~kg} \mathrm{BW}$ (Gondret et al., 2012). Thus, the older age at slaughter and possibly greater age-related decrease in lipogenic capacity with age in the B compared with the LW pigs may explain the lower lipogenic capacity of the B pigs. Regarding the BE pigs, both their much older age and lower feed allowance (Mersmann et al., 1981) may have contributed to their lower lipogenic capacity in SCAT compared with the BC pigs. As far as $\mathrm{C}$ and A systems are considered, differences in ME1 activity within the B breed might be related to the higher feed intake of the BA compared with BC pigs, whereas the lack of any changes in ME1 activity within the LW breed might be related to the similar feed intake of the LWA and LWC pigs. Overall, the lipid contents in SCAT and LM for all pigs were strongly associated with the hypertrophy of adipocytes in these tissues. This was expected regarding other data obtained on fat breeds compared with lean pig lines at both SCAT (Steele et al., 1974; Scott et al., 1981a; Mourot et al., 1996) and muscle (Hauser et al., 1997; Gondret and Lebret, 2002; Alfonso et al., 2005) levels.

Breed and production system also determined the fatty acid composition of SCAT. The greater proportion of MUFA, especially C18:1, and the lower proportion of PUFA, especially C18:2 n-6, in B pigs compared with LW pigs agree with the well-documented increase in MUFA and decrease in PUFA percentages with increased carcass adiposity (Lebret and Mourot, 1998; Wood et al., 2008 for reviews). In contrast, the lower proportion of SFA in the B pigs compared with LW pigs was opposite to the greater SFA proportion generally reported in fat lines when compared with lean pig lines at a constant age (Scott et al., 1981b) or a constant BW (Wood, 1984; Labroue et al., 2000). However, the breed-associated differences reported here in the proportions of stearic C18:0 and palmitic C16:0, the main SFA produced by novo lipogenesis, are in accordance with the lower activity of malic enzyme monitored in the SCAT of the B pigs compared with the LW pigs. The discrepancies between present data and the aforementioned studies may likely be explained by the much higher deposition rate of MUFA than SFA with increasing age. Whereas A vs. C system had only scarce influence on FA composition within breeds, the $\mathrm{E}$ production system in the $\mathrm{B}$ breed was associated with a much greater proportion of PUFA in SCAT when compared with $\mathrm{B}$ pigs produced in the $\mathrm{C}$ system. In agreement, an increase in PUFA proportion has been reported in adipose tissues of pigs reared in extensive systems on pasture, especially in slow-growing fat breeds (Lopez-Bote, 1998; Pugliese et al., 2005; Daza et al., 2007). The ratio of $\mathrm{C} 18: 2$ n- 6 to $\mathrm{C} 18: 3 \mathrm{n}-3$ was also higher in the $\mathrm{BE}$ than the $\mathrm{BC}$ pigs as a consequence of a much higher proportion in C18:2 n-6 in the BE pigs. Because experimental cold exposure results in lower C18:2 n-6 proportion in pig back fat (Lefaucheur et al., 1991), the changes observed between the $\mathrm{BE}$ and $\mathrm{BC}$ pigs in PUFA composition cannot be due to differences in ambient temperature. This might be related to feeding management, including both a reduced commercial diet supply and a modified feed composition associated with natural vegetal resources (grass, acorns, and chestnuts) in the BE group. Unfortunately, FA composition of the natural feed resources ingested by the BE pigs could not be determined in the present study.

A slight increase in the proportion of n-3 PUFA (except for $\mathrm{C} 22: 5)$ was also reported in the present study for the $\mathrm{BE}$ pigs compared with $\mathrm{BC}$ pigs, in agreement with the increase in the n-3 PUFA proportion generally 
found in fat tissues of pigs reared in extensive systems on pasture (Pugliese et al., 2005; Daza et al., 2007). The moderate increase in the n-3 FA in our study might be due to the low availability of grass in the E pen during the autumn-winter season, when the BE pigs underwent their finishing period.

In conclusion, the $\mathrm{E}$ rearing conditions counteract the growth rate as well as the fatness of the B breed, which has otherwise around 2-fold higher back fat thickness and intramuscular fat content than the LW breed under $\mathrm{C}$ or A housing conditions. The greater PUFA content encountered in back fat of pigs produced in the traditional system may contribute to the sensory specificity of pork products. Altogether, the present results confirm the major influence of breed on growth performance, carcass, and tissue composition and demonstrate that the production system of animals, especially the E system, can modulate the production traits and tissue characteristics in pigs.

\section{LITERATURE CITED}

Alfonso, L., J. Mourot, K. Insausti, J. A. Mendizabal, and A. Arana. 2005. Comparative description of growth, fat deposition, carcass and meat quality characteristics of Basque and Large White pigs. Anim. Res. 54:33-42.

Anderson, D. B., and R. G. Kauffman. 1973. Cellular and enzymatic changes in porcine adipose tissue during growth. J. Lipid Res. 14:160-168.

Anderson, D. B., R. G. Kauffman, and L. L. Kastenschmidt. 1972. Lipogenic enzyme activities and cellularity of porcine adipose tissue from various anatomical locations. J. Lipid Res. 13:593-599.

Arrayet, J., B. Montel, and J. Lossouarn. 2006. Small is beautiful. . but how to remain small? A case-study about the Basque swine. In: R. Rubino, L. Sepe, A. Dimitriadou, and A. Gibon, editors, Livestock farming systems: Product quality based on local resources leading to improved sustainability. Wageningen Academic Publishers, Wageningen, The Netherlands. p. 177-182.

Bazin, R., and P. Ferré. 2001. Assays in lipogenic enzymes. Methods Mol. Biol. 155:121-127.

Beattie, V. E., N. E. O'Connell, and B. W. Moss. 2000. Influence of environmental enrichment on the behaviour, performance and meat quality of domestic pigs. Livest. Prod. Sci. 65:71-79.

Bee, G., G. Guex, and W. Herzog. 2004. Free-range rearing of pigs during the winter: Adaptations in muscle fiber characteristics and effects on adipose tissue composition and meat quality traits. J. Anim. Sci. 82:1206-1218.

Bonneau, M., and B. Lebret. 2010. Production systems and influence on eating quality of pork. Meat Sci. 84:293-300.

Daza, A., A. Mateos, A. I. Rey, I. Ovejero, and C. J. Lopez-Bote. 2007. Effect of duration of feeding under free-range conditions on production results and carcass and fat quality of Iberian pigs. Meat Sci. 76:411-416.

Demars, J., J. Riquet, M. P. Sanchez, Y. Billon, J. F. Hocquette, B. Lebret, N. Iannuccelli, J. P. Bidanel, D. Milan, and F. Gondret. 2007. Metabolic and histochemical characteristics of fat and muscle tissues in homozygous or heterozygous pigs for the body composition QTL located on chromosome 7. Physiol. Genomics 30:232-241.
Enfält, A. C., K. Lundström, I. Hansson, N. Lundeheim, and P. E. Nyström. 1997. Effects of outdoor rearing and sire breed (Duroc or Yorkshire) on carcass composition and sensory and technological meat quality. Meat Sci. 45:1-15.

Folch, J., M. Lees, and G. H. Sloane Stanley. 1957. A simple method for the isolation and purification of total lipids from animal tissues. J. Biol. Chem. 226:497-509.

Gardan, D., F. Gondret, and I. Louveau. 2006. Lipid metabolism and secretory function of porcine intramuscular adipocytes compared with subcutaneous and perirenal adipocytes. Am. J. Physiol. Endocrinol. Metab. 291:E372-E380.

Gentry, J. G., J. J. McGlone, J. R. Blanton, and M. F. Miller. 2002. Alternative housing systems for pigs: Influences on growth, composition and pork quality. J. Anim. Sci. 80:1781-1790.

Gondret, F., B. Guevel, E. Com, A. Vincent, and B. Lebret. 2012. A comparison of subcutaneous adipose tissue proteomes in juvenile piglets with a contrasted adiposity underscored similarities with human obesity. J. Proteomics 75:949-961.

Gondret, F., and B. Lebret. 2002. Feeding intensity and dietary protein level affect adipocyte cellularity and lipogenic capacity of muscle homogenates in growing pigs, without modification of the expression of sterol regulatory element binding protein. J. Anim. Sci. 80:3184-3193.

Guy, J. H., P. Rowlinson, J. P. Chadwick, and M. Ellis. 2002. Growth performance and carcass characteristics of two genotypes of growing-finishing pig in three different housing systems. Anim. Sci. 74:493-502.

Hauser, N., J. Mourot, L. De Clercq, C. Genart, and C. Remacle. 1997. The cellularity of developing adipose tissues in Pietrain and Meishan pigs. Reprod. Nutr. Dev. 37:617-625.

Hood, R. L., and C. E. Allen. 1973. Lipogenic enzyme activity in adipose tissue during the growth of swine with different propensities to fatten. J. Nutr. 103:353-362.

Labroue, F., S. Goumy, J. Gruand, J. Mourot, V. Neelz, and C. Legault. 2000. Comparison with Large White of four local breeds of pigs for growth, carcass and meat quality traits. Journées Rech. Porcine 32:403-411.

Laval, G., N. Iannuccelli, C. Legault, D. Milan, M. A. M. Groenen, E. Giuffra, L. Andersson, P. H. Nissen, C. B. Jorgensen, P. Beeckmann, H. Geldermann, J. L. Foulley, C. Chevalet, and L. Ollivier. 2000. Genetic diversity of eleven European pig breeds. Genet. Sel. Evol. 32:187-203.

Lebret, B. 2008. Effects of feeding and rearing systems on growth, carcass composition and meat quality in pigs. Animal 2:1548-1558.

Lebret, B., and J. Mourot. 1998. Characteristics and quality of pig adipose tissues. Influence of rearing factors. INRA Prod. Anim. 11:131-143.

Lebret, B., M. C. Meunier-Salaün, A. Foury, P. Mormède, E. Dransfield, and J. Y. Dourmad. 2006. Influence of rearing conditions on performance, behavioral, and physiological responses of pigs to preslaughter handling, carcass traits, and meat quality. J. Anim. Sci. 84:2436-2447.

Lebret, B., A. Prunier, N. Bonhomme, A. Foury, P. Mormède, and J. Y. Dourmad. 2011. Physiological traits and meat quality of pigs as affected by genotype and housing system. Meat Sci. 88:14-22.

Lefaucheur, L., J. Le Dividich, J. Mourot, G. Monin, P. Ecolan, and D. Krauss. 1991. Influence of environmental temperature on growth, muscle and adipose tissue metabolism, and meat quality in swine. J. Anim. Sci. 69:2844-2854.

Lopez-Bote, C. J. 1998. Sustained utilization of the Iberian pig breed. Meat Sci. 49:S17-S27.

Mersmann, H. J., C. D. Allen, E. Y. Chai, J. L. Brown, and T. J. Fogg. 1981. Factors influencing the lipogenic rate in swine adipose tissue. J. Anim. Sci. 52:1298-1305. 
Millet, S., C. P. H. Moons, M. J. Van Oeckel, and G. P. J. Janssens. 2005. Welfare, performance and meat quality of fattening pigs in alternative housing and management systems: A review. J. Sci. Food Agric. 85:709-719.

Morrison, W. R., and L. M. Smith. 1964. Preparation of fatty acid methyl esters and dimethyl acetals from lipids with boron fluoride-methanol. J. Lipid Res. 5:600-608.

Mourot, J., M. Kouba, and M. Bonneau. 1996. Comparative study of in vitro lipogenesis in various adipose tissues in the growing Meishan pig. Comparison with the Large White pig. Comp. Biochem. Physiol. 115:383-388.

Patton, B. S., E. Huff-Lonergan, M. S. Honeyman, J. D. Crouse, B. J. Kerr, and S. M. Lonergan. 2008. Effects of deep-bedded finishing system on market pig performance, composition and pork quality. Animal 2:459-470.

Pugliese, C., R. Bozzi, G. Campodoni, A. Acciaioli, O. Franci, and G. Gandini. 2005. Performance of Cinta Senese pigs reared outdoors and indoors. 1. Meat and subcutaneous fat characteristics. Meat Sci. 69:459-464.

Pugliese, C., and F. Sirtori. 2012. Quality of meat and meat products produced from southern European pig breeds. Meat Sci. 90:511-518.

Renaudeau, D., and J. Mourot. 2007. A comparison of carcass and meat quality characteristics of Creole and Large White pigs slaughtered at 90kg BW. Meat Sci. 76:165-171.

Sather, A. P., S. D. M. Jones, A. L. Schaefer, J. Colyn, and W. M. Robertson. 1997. Feedlot performance, carcass composition and meat quality of free-range reared pigs. Can. J. Anim. Sci. 77:225-232.

Schwab, C. R., T. J. Baas, K. J. Stalder, and J. W. Mabry. 2006. Effect of long-term selection for increased leanness on meat and eating quality traits in Duroc swine. J. Anim. Sci. 84:1577-1583.
Scott, R. A., S. G. Cornelius, and H. J. Mersmann. 1981a. Effects of age on lipogenesis and lipolysis in lean and obese swine. J. Anim. Sci. 52:505-511.

Scott, R. A., S. G. Cornelius, and H. J. Mersmann. 1981b. Fatty acid composition of adipose tissue from lean and obese swine. J. Anim. Sci. 53:977-981.

Sellier, P. 1998. Genetics of meat and carcass traits. In: M. F. Rotschild and A. Ruvinsky, editors, The genetics of the pig. CAB International, Wallingford, UK. p. 463-510.

Steele, N. C., and L. T. Frobish. 1976. Selected lipogenic enzyme activities of swine adipose tissue as influenced by genetic phenotype, age, feeding frequency and dietary energy source. Growth 40:369-378.

Steele, N. C., L. T. Frobish, and M. Keeney. 1974. Lipogenesis and cellularity of adipose tissue from genetically lean and obese swine. J. Anim. Sci. 39:712-719.

Stewart, T. S., D. L. Lofgren, D. L. Harris, M. E. Einstein, and A. P. Schinckel. 1991. Genetic improvement programs in livestock: Swine testing and genetic evaluation system (stages). J. Anim. Sci. 69:3882-3890.

Tribout, T., J. C. Caritez, J. Gruand, M. Bouffaud, P. Guillouet, Y. Billon, C. Péry, E. Laville, and J. P. Bidanel. 2010. Estimation of genetic trends in French Large White pigs from 1977 to 1998 for growth and carcass traits using frozen semen. J. Anim. Sci. 88:2856-2867.

Wood, J. D. 1984. Fat deposition and the quality of fat tissue in meat animals. In: J. Wiseman, editor, Fats in animal nutrition. Butterworths, London, UK. p. 407-435.

Wood, J. D., M. Enser, A. V. Fisher, G. R. Nute, P. R. Sheard, R. I. Richardson, S. I. Hughes, and F. M. Whittington. 2008. Fat deposition, fatty acid composition and meat quality: A review. Meat Sci. 78:343-358. 
References

This article cites 43 articles, 19 of which you can access for free at: http://www.journalofanimalscience.org/content/92/8/3543\#BIBL 